\title{
MODEL SISTEM DINAMIS: SIMULASI FORMULASI KEBIJAKAN PUBLIK
}

\author{
(Dynamic System Model: Simulation Method in Formulation Public Policy)
}

\author{
Lesmana Rian Andhika \\ IImu Administrasi Fakultas IImu Sosial dan IImu Politik, Universitas Padjadjaran \\ Jl. Bukit Dago Utara No. 25, Bandung 40135, \\ Email: lesmana15001@mail.unpad.ac.id
}

Naskah diterima: 9 April 2019

Naskah direvisi: 20 April 2019

Naskah diterbitkan: 30 Juni 2019

\begin{abstract}
The Dynamic System Model can be practical decision-making tools that allow testing various scenarios of policy formulation. This study focuses on describe policy formulation in a simulation using Dynamic System Model, the purpose of applying the model is to observe a variety of complex structures and may influence the objectives based on the phenomenon of the identified problem. Furthermore, Dynamic System Model can see changes in policy behavior and allow feedback schemes to provide information flows to design complex policy formulations. This study was conducted with a meta-data-analysis approach, aimed to develop systematic knowledge of certain phenomena through analysis of data processed from selected secondary data. To develop argumentation, this study also refers to several cases of previous research and treated as evidence. The results of this study provide information that in a policy formulation simulation model with a dynamic system used aspects of analysis, planning, and control. These three aspects provide a means for assessing the possible causes of irregularities, resulting variety of possible analyzes of various sources of information, methods, references to determine feedback from all related analyzes in a dynamic system. Thus, provide an early warning about the need for further action, but from these three aspects might have an effect, change and deviation from one part of the system, and often differ from what was intended. For this reason, irregularities provide a signal for additional analysis, whether the policy/strategy has been effectively implemented.
\end{abstract}

Keywords: simulation, model, dynamic system, policy formulation

\begin{abstract}
Abstrak
Model Sistem Dinamis dapat menjadi alat pendukung pengambilan keputusan praktis yang memungkinkan untuk menguji berbagai skenario formulasi kebijakan. Penelitian ini berfokus untuk menggambarkan Model Sistem Dinamis formulasi kebijakan dalam sebuah simulasi, tujuan dari penerapan model tersebut untuk mengamati berbagai struktur yang kompleks, dan mungkin memengaruhi tujuan berdasarkan fenomena masalah yang teridentifikasi. Selain itu, Model Sistem Dinamis dapat melihat perubahan perilaku kebijakan dan memungkinkan skema umpan balik untuk memberikan arus informasi merancang formulasi kebijakan yang lebih kompleks. Penelitian ini dilakukan dengan pendekatan meta-data-analysis, bertujuan untuk mengembangkan pengetahuan secara sistematis tentang fenomena tertentu melalui analisis data yang diolah dari data sekunder terpilih. Untuk mengembangkan argumentasi penelitian ini juga merujuk kepada beberapa kasus penelitian terdahulu dan diperlakukan sebagai bukti. Hasil penelitian ini memberikan informasi bahwa dalam model simulasi formulasi kebijakan dengan sistem dinamis digunakan aspek analysis, planning, dan control. Ketiga aspek ini menyediakan sarana untuk menilai kemungkinan penyebab penyimpangan, menghasilkan berbagai kemungkinan analisis dari berbagai sumber informasi, metode, referensi untuk menetapkan umpan balik dari semua analisis yang terkait dalam sistem dinamis. Dengan demikian memberikan peringatan dini tentang perlunya tindakan lebih lanjut, namun dari ketiga aspek tersebut mungkin menimbulkan efek, perubahan dan penyimpangan satu bagian dari sistem, dan sering berbeda dari pada yang dimaksudkan. Untuk itu penyimpangan memberikan sinyal untuk analisis tambahan, apakah kebijakan/strategi telah diterapkan secara efektif.
\end{abstract}

Kata kunci: simulasi, model, sistem dinamis, formulasi kebijakan

\section{PENDAHULUAN}

Kebijakan publik telah didefinisikan oleh para praktisi dan akademisi dengan berbagai interpretasi, kebijakan publik merupakan prinsip tindakan yang mengatur aktivitas pemerintah dan masyarakat dengan cara konsisten melalui hukum yang berlaku. Kebijakan di area tertentu dapat memberikan keuntungan, dapat meningkatkan perekonomian sebuah negara dengan mekanisme tertentu yang diatur oleh kebijakan nasional (Henriksen, 2013). Dalam aktivitas pemerintah, kebijakan merupakan petunjuk dan landasan hukum untuk melakukan serangkaian kegiatan yang telah diatur (Dye, 2013). Kebijakan publik juga dapat meningkatkan atau menurunkan kepercayaan publik terhadap pemerintah (Aghion, et al., 2010). Jika kebijakan pemerintah bertujuan mulia maka sangat membantu para administrator dan manajer pemerintah untuk menjalankan fungsinya. Namun banyak kebijakan bertujuan untuk melegalkan kepentingan kelompok tertentu tanpa memerhatikan akibat dari berlakunya kebijakan tersebut. Kebijakan akan menjadi tidak efektif apabila awal dari perumusannya tidak dilakukan dengan prosedur yang benar. 
Akibatnya terjadi sengketa yang mempersoalkan lahirnya kebijakan tersebut atau dengan kata lain bahwa kebijakan tersebut merugikan kepentingan umum dan bertentangan dengan peraturan yang lebih tinggi sehingga berbagai kalangan akan mengajukan pengujian (judicial review). Sebagai contoh, kebijakan penggunaan Liquefied Petroleum Gas (LPG) $3 \mathrm{~kg}$ (Peraturan Pemerintah No. 104 Tahun 2007 tentang Penyediaan, Pendistribusian dan Penetapan Harga Liquefied Petroleum Gas Tabung 3 Kilogram) untuk masyarakat miskin yang disubsidi, namun dalam praktiknya kelangkaan, harga eceran tertinggi (HET) tidak sesuai dengan kebijakan yang ada. Sehingga berbagai usaha mencari masalah diterapkan sebagai dasar untuk menerbitkan kebijakan yang baru. Bovens \& Hart (2016) mengklaim bahwa kegagalan kebijakan bukanlah upaya atau peristiwa yang netral, biasanya secara implisit maupun eksplisit disebabkan oleh narasi penuntutan, permainan, dan pencarian penyebab utama. Namun keinginan para pembuat kebijakan selalu akan menghindari kesalahan yang menyebabkan kebijakan yang buruk dan menyadari untuk mencari cara terbaik menghindari kegagalan kebijakan (Howlett, 2011, 2012).

Oleh sebab itu, kebijakan publik yang telah diberlakukan pemerintah belum tentu akan berhasil dalam implementasi, atau keberadaan kebijakan tersebut tidak memberikan manfaat yang lebih besar kepada masyarakat luas terutama derivate kebijakan tingkat lokal. Laporan Kementerian Dalam Negeri menyebutkan terdapat sekitar 3.143 peraturan yang dibatalkan, 1.765 peraturan daerah (Perda)/ peraturan kepala daerah (Perkada) yang dicabut/ direvisi Menteri Dalam Negeri, 111 Peraturan/ Putusan Menteri Dalam Negeri dicabut/direvisi Menteri Dalam Negeri, dan 1.267 Perda/Perkada yang dicabut/direvisi oleh Gubernur (Kemendagri, 2016). Oleh sebab itu, proses kebijakan semestinya dilakukan dengan benar karena proses kebijakan pada dasarnya adalah studi tentang pelaksanaan kekuatan dalam pembuatan kebijakan. Tidak hanya pada tingkat daerah namun kebijakan tingkat pusat juga masih terjadi polemik dan kontroversi dengan mengeluarkan aturan yang merugikan masyarakat. Seperti kebijakan larangan ojek maupun taksi yang berbasis daring (online) oleh Kementerian Perhubungan, kebijakan full day school oleh Kementerian Pendidikan dan Kebudayaan, dan pembatalan kebijakan kenaikan harga premium oleh Kementerian Energi dan Sumber Daya Mineral (ESDM). Dari beberapa data dan fakta yang terungkap tersebut maka Aghion, et al., (2010) dan Bovens \& Hart (2016) dalam studinya mengungkapkan bahwa produk kebijakan yang buruk dapat memengaruhi kehidupan masyarakat.
Selain itu, inkonsisten para pembuat kebijakan berakibat pada dampak kebijakan dari proses umpan balik yang membentuk legitimasi, koherensi, dan daya tahan kebijakan. Dengan demikian sebelum kebijakan dibentuk diperlukan serangkaian kegiatan yang komprehensif untuk menghimpun informasi sebagai dasar merumuskan kebijakan. Salah satu kegiatan tersebut adalah "difusi kebijakan", sebuah kegiatan yang digunakan untuk belajar dari kebijakan yang sukses pada daerah lain (Bender, et al., 2014; Maggetti \& Gilardi, 2015). Ketika pemerintah memutuskan mengadopsi sebuah kebijakan mungkin saja terjadi karena adanya tuntutan dari masyarakat atau dari percobaan pemerintah untuk mengadopsi kebijakan baru. Namun kegiatan seperti ini sering dilakukan dengan kegiatan studi banding oleh pembuat kebijakan, dan menghabiskan anggaran negara yang tidak sedikit. Berbagai informasi dari media dapat dengan mudah ditelusuri bahwa studi banding sering mendapatkan protes dari berbagai kalangan dengan mempertanyakan efisiensi dan manfaat yang didapat. Argumentasi serupa juga pernah diungkapkan oleh Gilardi (2016) dalam studinya bahwa kegiatan difusi kebijakan sering menimbulkan inefisiensi anggaran pemerintah karena kebijakan yang di adopsi tidak berasal dari daerah yang memiliki karakteristik yang hampir serupa.

Oleh sebab itu, Model Sistem Dinamis berupaya untuk menganalisis kemungkinan-kemungkinan yang dapat terjadi sebagai bahan informasi formulasi kebijakan yang lebih kompleks, berbagai kegiatan seperti konseptualisasi, formulasi dan penggunaan aplikasi komputer memudahkan untuk menerjemahkan data-data empiris yang dihimpun. Dibandingkan dengan difusi kebijakan maka Barlas (2002); Groff (2013); Sayyadi \& Awasthi (2016) menunjukkan kelebihan Model Sistem Dinamis, pertama memahami fenomena yang kompleks, hal ini diindikasikan sebagai upaya memahami apa yang terjadi secara aktual. Kedua, dibutuhkan konseptualisasi untuk menggambarkan perilaku dari setiap kebijakan yang menjadi rujukan, hal ini berarti Model Sistem Dinamis membutuhkan lebih banyak pengetahuan untuk memikirkan berbagai hal yang dapat memengaruhi kebijakan. Ketiga, untuk formulasi kebijakan dalam kasus suatu fenomena harus merepresentasikan detail prosedur kegiatan, orang yang terlibat, dan faktor kemungkinan yang mendapatkan pengaruh (lihat lebih lanjut Sterman, 2000).

Perumusan dan proses perubahan kebijakan publikkiniakan lebih banyak ditentukan oleh kekuatan dan kepentingan-kepentingan eksternal. Oleh sebab itu, Dunn (2016) memberikan keterangan bahwa 
kebijakan publik merupakan proses kegiatan yang bersifat politis. Proses itu menerangkan serangkaian tahap yang saling bergantung antara agenda setting, policy formulation, policy adoption, policy implementation, and policy evaluation. Meskipun diterima secara luas bahwa kebijakan publik sulit untuk diimplementasikan, sebagian besar analisis kegagalan kebijakan dianggap sebagai proses yang paling rasional. Studi kebijakan publik mengajarkan beberapa tahap dalam proses kebijakan mempunyai pekerjaan dan tujuan yang berbeda, walaupun pada akhirnya akan dievaluasi kembali (Hill, 2005; Stewart, 2009).

Sebagai contoh, jika formulasi kebijakan adalah proses mengidentifikasi dan mengatasi kemungkinan berbagai solusi untuk masalah kebijakan, maka formulasi kebijakan dapat mengeksplorasi berbagai pilihan atau alternatif yang tersedia untuk mengatasi masalah. Kemudian mengembangkan atau menggunakan alat yang tersedia untuk mengatasi masalah perumusan kebijakan (Howlett, 2011). Selanjutnya Howlett (2011) mengingatkan bahwa perumusan kebijakan adalah bagian penting dari proses kebijakan, dan mungkin sangat sulit untuk memahami perumusan kebijakan, walaupun dengan benar mempelajarinya tanpa berpikir untuk menggunakan alat bantu untuk memahami setiap unsur yang terkandung dalam formulasi kebijakan.

Oleh sebab itu, penelitian ini ingin mendiskusikan lebih jauh formulasi kebijakan dengan menggunakan alat bantu Dynamic System Model. Beberapa studi yang pernah dilakukan memberikan informasi bahwa implementasi kebijakan publik dapat meningkatkan kemampuan berpikir operasional yang diperlukan untuk merancang struktur model kebijakan untuk sektor publik dengan sistem dinamis (Wheat, 2010). Keseluruhan tahap proses pengambilan kebijakan publik dapat menerapkan sistem dinamis untuk mengatasi kesulitan dari faktor lingkungan yang berada dekat dengan proses pembuatan kebijakan publik (Ghaffarzadegan, et al., 2011). Sistem dinamis dapat menilai implikasi dari sebuah kebijakan dan dapat digunakan untuk panduan mendesain kebijakan (Groff, 2013).

Walaupun studi terdahulu meletakkan pondasi yang penting untuk memahami manfaat sistem dinamis dalam proses kebijakan, namun terdapat catatan yang perlu didiskusikan lebih jauh karena jarang didiskusikan oleh studi terdahulu. Misalnya, dalam proses formulasi kebijakan apakah model ini tepat, karena model dinamis sering digunakan untuk menggambarkan kompleksitas masalah dalam dunia industri. Sistem dinamis sering digunakan untuk menilai implikasi kebijakan, implementasi, dan proses kebijakan secara simultan. Setidaknya saat ini sistem dinamis telah banyak diintroduksi untuk mengetahui sejauh mana kebijakan berhasil atau tidak, dan apa penyebab kebijakan tersebut perlu direvisi kembali. Tujuan penelitian ini untuk mendiskusikan dan menggambarkan lebih jauh simulasi Model Sistem Dinamis (Dynamic System Model) dalam proses formulasi kebijakan. Langkah yang ditempuh untuk memperkuat argumentasi dan diskusi, penelitian ini terdiri dari beberapa langkah, yaitu menjelaskan tujuan model, berarti berfokus pada masalah dan mempersempit model sebelum menyatakan tujuan model yang konkret. Mendefinisikan batas model, melibatkan pemilihan komponen yang diperlukan dan ditetapkan oleh tujuan model. Dengan demikian prinsip kerja sistem dinamis, seperti cause and effect, feedback, dan karakterisitik, turut dibahas pada bagian hasil dan pembahasan.

\section{METODE}

Penelitian ini dilakukan dengan pendekatan synthesis of qualitative research (meta-narrative synthesis, critical interpretive synthesis, metastudy, meta-ethnography, grounded formal theory, thematic synthesis, textual narrative synthesis, framework synthesis, and ecological triangulation). Lebih spesifik kepada meta-study, Barnett \& Thomas (2009) menjelaskan, meta-study mempunyai tiga komponen analisis, yakni meta-data-analysis (the analysis of findings), meta-method (the analysis of methods), and meta-theory (the analysis of theory). Untuk mengembangkan argumentasi dan konseptualisasi maka penelitian ini menggunakan meta-data-analysis untuk analisis data yang diolah dari data sekunder terpilih seperti studi ilmiah yang pernah dipublikasikan (jurnal, buku ilmiah), dan peraturan pemerintah yang terkait dengan tema penelitian untuk mengembangkan pengetahuan secara sistematis tentang fenomena tertentu (Paterson, et al., 2001). Data yang terpilih atau relevan (jurnal, buku ilmiah, dan peraturan pemerintah) dengan kajian penelitian ini akan digunakan untuk membangun sebuah model simulasi (System Dynamics Models in Policy and Strategy Formulation) yang berkaitan dengan tema penelitian. Batasan model simulasi yang dibangun dalam penelitian ini didasarkan pada analisis (identifikasi struktur masalah), perencanaan (strategi yang akan digunakan untuk menggambarkan fenomena yang telah teridentifikasi, dan memicu sensitivitas strategi untuk dapat bekerja dengan penerapan identifikasi, seleksi dan evaluasi strategi). Batasan terakhir adalah kontrol terhadap kinerja yang diharapkan dan efisiensi model (dilakukan dengan cara menarik umpan balik dari setiap argumentasi, konseptualisasi, dan perdebatan antara pembuat kebijakan serta 
diuji coba terhadap faktor eksternal seperti tren atau dampak yang sedang terjadi sesuai dengan konteks dan sasaran kebijakan agar lebih konsisten dengan kenyataan yang aktual).

Dalam meta-data-analysis, analisis data dilakukan dengan membandingkan masing-masing studi yang terpilih sehingga memberikan informasi yang dapat direduksi untuk mengembangkan pengetahuan. Langkah-langkah analisis data melalui proses-proses penjabaran yang terkait dengan fenomena, mengklasifikasikannya, dan melihat bagaimana beberapa konsep saling berhubungan (Dey, 1993). Penelitian ini juga merujuk kepada beberapa kasus studi yang terpilih, dan dijadikan sebagai bukti untuk memperkuat argumentasi yang telah dibangun sebelumnya. Selain itu, gambar, tabel, garis, superscript, dan angka digunakan untuk mencari realitas argumentasi yang sesuai. Selain itu, penelitian ini akan menyimpulkan hasil penelitian dengan hati-hati melalui teknik cross-check.

\section{HASIL DAN PEMBAHASAN}

\section{Memahami Dynamic System Model}

System Dynamic pertama kali dibangun dan disusun oleh Jay W. Forrester dalam sebuah proyek di Massachussets Institute of Technology (MIT) pada tahun 1956. Sistem dinamis menggambarkan sebuah sistem yang selalu berubah sepanjang waktu secara terus menerus. Sebuah model untuk membentuk suatu management flight simulator, dalam mempelajari kompleksitas dinamis, juga pola dari variabel dan strukturnya sepanjang waktu. Selain itu, sistem dinamis mampu melihat perilaku sistem pada

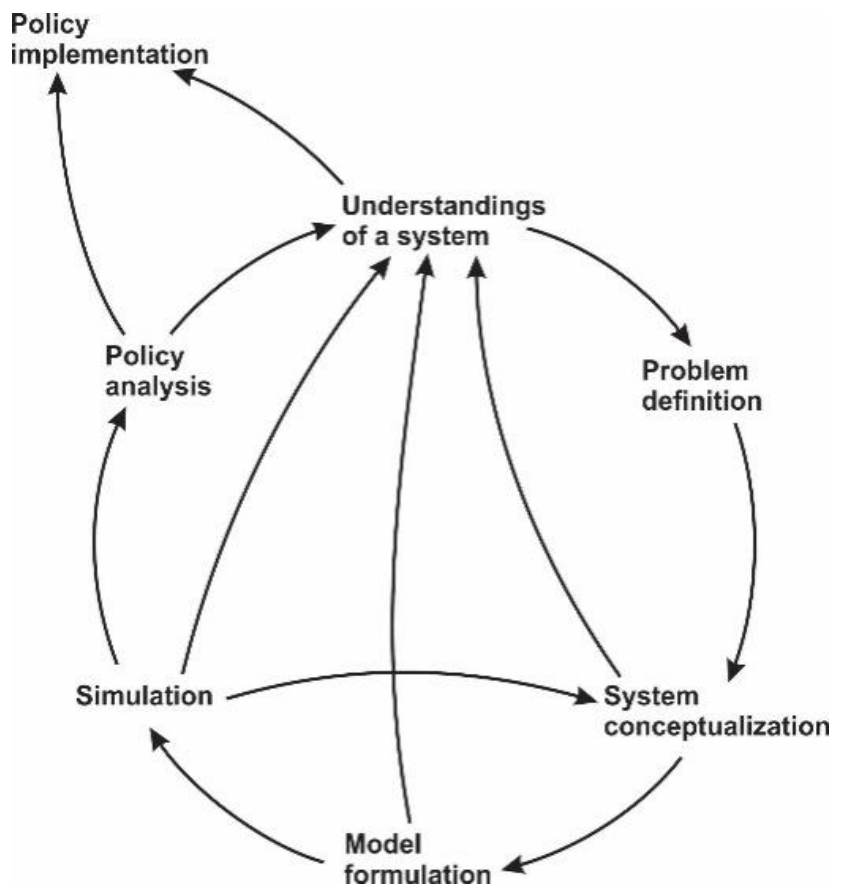

Sumber: Richardson \& Pugh (1981).

Gambar 1. Ikhtisar Pendekatan Model Sistem Dinamis masa lampau ataupun memrediksi masa yang akan datang untuk mengerti sumber resistensi kebijakan, dan mendesain kebijakan yang lebih efektif.

Konsep dasar sistem dinamis seperti yang dijelaskan oleh Richardson \& Pugh (1981) divisualisasikan pada Gambar 1. Pendekatan sistem dinamis digunakan untuk mengatasi masalah yang kompleks serta berfokus pada proses umpan balik. Bahwa struktur umpan balik bertanggung jawab atas perubahan dari waktu ke waktu. Oleh sebab itu, konsep dasar Model Sistem Dinamis terdapat sekitar tujuh tahap dalam mendekati masalah, yaitu problem identification and definition, system conceptualization, model formulation, analysis of model behavior, model evaluation, policy analysis, dan model use or implementation. Sebagai penyebab dan konsekuensi dari perspektif umpan balik, pendekatan sistem dinamis cenderung mencari sumber perilaku masalahnya. Masalah disebabkan oleh agen eksternal di luar sistem, dalam praktiknya sudut pandang internal menghasilkan model sistem umpan balik yang membawa agen eksternal ke dalam sistem. Penggunaan Model Sistem Dinamis dalam studi kebijakan digunakan untuk mendapatkan berbagai opsi kebijakan pada negara-negara maju, sebagian negara berkembang, dan sering digunakan untuk proses kebijakan di berbagai sektor dengan mempertimbangkan kausalitas di antara beberapa kemungkinan yang memengaruhi.

Istilah dinamis hampir sama dengan timeevolution atau pattern of change. Sistem dinamis adalah sebuah model dalam ilmu matematika. Biasanya digunakan dalam menganalisis konsep engineering disciplines, seperti electrical, mechanical, civil, dan chemical engineering dan berkembang untuk menganalisis berbagai model pendekatan dalam studi ekonomi, demografi, dan sosial. Namun banyak sistem dinamis dapat dipahami dan dianalisis secara intuitif, tanpa menggunakan matematika dan tanpa pengembangan teori dinamika umum (lihat lebih lanjut Luenberger, 1979; Richardson \& Pugh, 1981; Rowell \& Wormley, 1997). Hampir semua fenomena yang diamati dalam kehidupan kita sehari-hari atau dalam penelitian ilmiah memiliki aspek dinamis yang penting. Studi kebijakan merupakan seperangkat aturan yang ada dalam pemerintah, sektor bisnis, maupun organisasi non pemerintah. Kebijakan tidak hanya bercerita tentang cara perumusan, pelaksanaan dan evaluasi, yang terpenting kebijakan tersebut akan menimbulkan berbagai implikasi, kausalitas, memberikan perubahan pada struktur organisasi, ekonomi, pengembangan sosial budaya dan berbagai area. Implikasi ini yang seharusnya dapat dipahami sebagai situasi dinamis yang menunjukkan potensi pengembangan perencanaan kebijakan tingkat 
lanjut untuk mewakili dan menganalisis dinamika perubahan yang menyebabkan kebijakan baik atau tidak (Duggan, 2016).

Sebagai contoh "Paket Kebijakan Ekonomi" yang telah diluncurkan oleh pemerintah. Dasar dari diterbitkannya paket kebijakan ekonomi tersebut berupaya untuk menjamin iklim investasi dan mendorong prekonomian negara. Namun dalam pandangan Model Sistem Dinamis, kita dapat mengidentifikasi faktor apa yang menyebabkan paket kebijakan ekonomi tersebut terbit. Richardson \& Pugh (1981) mensimulasikan lingkaran (loop) yang saling terhubung. Pertama dalam konteks "Paket Kebijakan Ekonomi", identifikasi masalah berasal dari lemahnya regulasi, birokratisasi, penegakan hukum, dan kepastian usaha. Setelah itu, sistem yang dibangun berlandaskan asas transparansi, akuntabilitas, dan kompetitif. Oleh sebab itu, formulasi kebijakan dan analisis perilaku kebijakan itu sendiri berasal dari informasi yang dihimpun dari identifikasi masalah dan sistem yang hendak diimplementasikan. Di samping itu, analisis kebijakan akan menilai sejauh mana paket kebijakan ekonomi tersebut memberikan manfaat yang lebih besar sehingga menjadi dasar untuk menerbitkan paket kebijakan ekonomi selanjutnya (terjadi penerbitan paket kebijakan ekonomi sebanyak 16 penerbitan selama Pemerintahan Presiden Joko Widodo). Namun penerbitan beberapa "Paket Kebijakan Ekonomi" diindikasikan untuk mencari model yang sesuai berdasarkan identifikasi situasi masalah yang terus dan setiap waktu dapat berubah.

Howlett (2011) mendukung argumentasi yang telah diuraikan sebelumnya, ia menyebutkan bahwa desain kebijakan adalah subjek yang kompleks dengan banyak nuansa dan variasi untuk dipertimbangkan. Setelah pemerintah mengakui adanya masalah publik dan kebutuhan untuk melakukan sesuatu maka akan masuk ke dalam agenda pemerintah, pembuat kebijakan diharapkan dapat memutuskan tindakan yang harus diambil untuk mengatasinya. Selain itu, perumusan kebijakan mengacu pada tahap menghasilkan opsi tentang apa yang harus dilakukan terhadap masalah publik. Ini adalah tahap di mana opsi-opsi yang dapat membantu menyelesaikan masalah dan masalah yang diakui pada tahap penetapan agenda diidentifikasi, diperbaiki, dinilai, dan diformalkan.

\section{Kompleksitas Karakteristik Model Dinamis}

Pertama-tama, untuk memahami Model Sistem Dinamis yang perlu diperhatikan adalah pemahaman tentang fenomena. Karena fenomena dapat menjadi dasar penggunaan Model Sistem Dinamis (Homer \& Hirsch, 2006; Groff, 2013; Uriona \& Grobbelaar,
2018). Fenomena terdiri dari dua hal, yaitu struktur (untuk yang membentuk fenomena, atau pola keterkaitan) dan perilaku (berkaitan tentang perubahan suatu variabel dalam kurun waktu tertentu). Fenomena menjadi unsur pembentuk sistem, dipahami sebagai suatu fenomena yang kompleks (Ghaffarzadegan, et al., 2011). Di sisi yang lain pemahaman tentang hubungan struktur dan perilaku diperlukan untuk mengenali suatu fenomena. Sebagai contoh, kebijakan pemerintah daerah tentang penguatan ekonomi kerakyatan. Secara umum tujuan kebijakan merupakan tindakan yang disengaja dalam mengejar beberapa tujuan tertentu, dan sasaran kebijakan muncul dari kegiatan penetapan agenda kebijakan (Hill, 2005; Stewart, 2009). Oleh sebab itu, dasar kebijakan tersebut terjadi melalui serangkaian proses kegiatan seperti menganalisis fenomena ekonomi, pendapatan, tingkat konsumsi, daya saing, dan pengeluaran yang terjadi dalam proses formulasi kebijakan. Akibatnya pemahaman tentang struktur yang berkaitan dengan kausalitas fenomena cenderung akan terukur. Di samping itu, kemungkinan perilaku berkaitan dengan "jika" kebijakan tersebut dapat merubah ekonomi, pendapatan, tingkat konsumsi, daya saing, dan pengeluaran. Oleh sebab itu, fenomena hadir karena kesenjangan antara keadaan yang sebenarnya (actual state) dengan keadaan yang diinginkan (goal).

Kedua, mengenali struktur fisik (jaringan informasi dan materi) dan struktur pembuatan keputusan (decision-making structure) dengan kaidah pembuatan keputusan dengan menggunakan sumber informasi untuk pengambilan keputusan. Ketiga, kurangnya pemahaman tentang kompleksitas sistem mengakibatkan kemungkinan keputusan kebijakan tidak memerhatikan dan memahami mengapa sistem yang kompleks dari interaksi agen dari waktu ke waktu dapat merubah perilaku kebijakan (berkaitan tentang perubahan suatu variabel kebijakan).

\section{Tujuan Model}

Dynamic System Model dapat membangun hubungan kausalitas yang diperlukan dalam proses formulasi kebijakan, dan juga mencakup semua entitas hubungan utama efek kausalitas. Oleh sebab itu, sistem dinamis ini juga sebagai alat mendukung setiap keputusan praktis yang memungkinkan untuk menguji efektivitas berbagai skenario kebijakan (Rashedi \& Hegazy, 2015; Bérard, et al., 2016). Sebagai contoh dalam perumusan kebijakan mesti memerhatikan aspek "tujuan, strategi, program, dan kebijakan pendukung." Studi baru-baru ini juga mengidentifikasi bahwa kecenderungan studi tentang Model Sistem Dinamis dalam kebijakan publik digunakan untuk kebijakan yang berorientasi 
kepada penelitian dan pengembangan ( $R \& D$ policies), kebijakan inovasi (innovation diffusion policies), pengetahuan dan teknologi (science and technology policies), dan pengelompokkan kebijakan tingkat lokal (Uriona \& Grobbelaar, 2018).

Sistem dinamis juga dikenal sebagai sistem yang tidak statis, artinya respons sistem dapat berubah setiap saat sehubungan dengan variabel yang diidentifikasi (waktu, kondisi lingkungan, dan sebagainya). Untuk itu Model Sistem Dinamis adalah model yang mencoba memprediksi atau merespon proses perubahan tersebut. Model Dinamis mengasumsikan hubungan dan memprediksi input sebagai fungsi dari berbagai variabel yang teridentifikasi. Sterman (2000) mengidentifikasi tujuan mempelajari Model Sistem Dinamis, pertama, yaitu complexity of dynamic systems, bounded rationality and misperceptions of feedbacks and delays (descriptive model) model ini mengukur perilaku kompleksitas dalam konteks dengan skenario lingkungan, dimungkinkan untuk menetapkan batas pada kompleksitas absolut (maksimum) sistem dan memperkirakan kompleksitas totalnya. Namun pendekatan-pendekatan yang memberikan definisi terukur untuk kompleksitas absolut dari suatu sistem sering memaksakan persyaratan pengetahuan yang sempurna atau hampir sempurna dari struktur sistem.

Kedua, limited information (simulation model) model ini hanya mengidentifikasi simulasi dinamika sistem yang serupa, menerima umpan balik hasil yang sempurna, langsung, tidak terdistorsi, dan lengkap dari berbagai informasi yang relevan. Ketiga, wrong deductions re. the dynamic behavior of systems (model validation and analysis) model ini mencakup analisis sebagian besar dinamika sistem, seperti "stasis" atau keseimbangan, di mana keadaan sistem tetap konstan dari waktu ke waktu, dan variasi acak. Keempat, defensive routines and personal emotional involvement (alternative scenarios) model ini dapat beroperasi di laboratorium pembelajaran seperti halnya dalam organisasi yang sebenarnya. Namun pembelajaran yang efektif di dunia virtual seperti pengujian hipotesis publik, akuntabilitas, dan perbandingan strategi yang berbeda dapat memicu reaksi defensif yang mencegah pembelajaran.

Di sisi lain penggunaan dynamic system model sebagai petunjuk untuk pengembangan kebijakan (Coyle, 1996). Petunjuk tersebut diterjemahkan dalam aktivitas memahami komponen kebijakan itu seperti struktur kebijakan. Struktur kebijakan merujuk kepada sesuatu yang disusun dengan pola tertentu. Struktur yang tekandung dalam setiap kebijakan memiliki aspek filosofis, nilai, norma, pengaruh (lihat lebih lanjut Kay, 2006). Oleh sebab

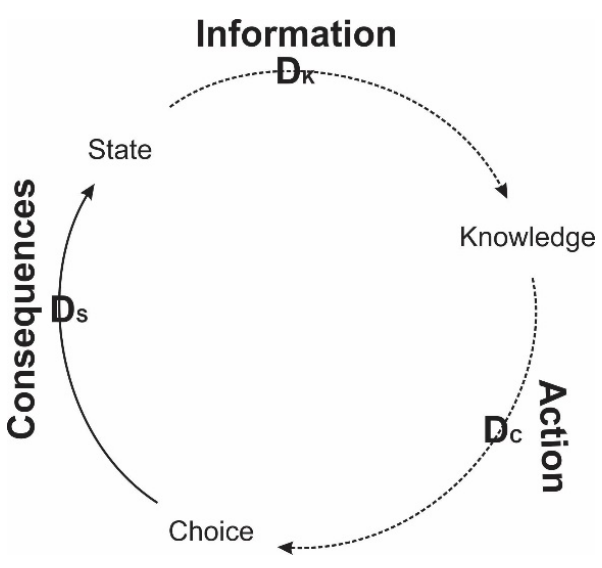

Sumber: Coyle (1996)

Gambar 2. Paradigma Model Sistem Dinamis (Informasi, Tindakan dan Konsekuensi)

itu, penggunaan Dynamic System Model akan lebih mungkin menghasilkan kebijakan yang berkualitas dengan mempertimbangkan efek dari kebijakan itu sendiri terhadap berbagai aktivitas di sektor lain. Pada tahap perumusan kebijakan model ini akan mengidentifikasi kausalitas dari berbagai sektor/ konsep, teori/disiplin ilmu yang mungkin akan memengaruhi secara signifikan. Lebih lanjut Coyle (1996) menjelaskan bahwa Model Sistem Dinamis setidaknya mengandung consequences, information, dan action untuk menyatakan prosedur dan tujuan, yang kemudian divisualisasikan seperti pada Gambar 2.

Kemudian Coyle (1996) memberikan ilustrasi penjelasan keadaan sistem yang dinamis dimulai dengan mengikuti "loop" atau putaran sistem. Dalam penelitian ini menunjukkan bahwa formulasi kebijakan berasal dari pilihan yang dibuat oleh para pembuat kebijakan yang terlibat. Seperti, menghimpun berbagai sumber informasi sebagai alat analisis formulasi. Huruf " $D$ " besar pada tautan choice to state menginggatkan kita bahwa pada umumnya terjadi penundaan yang substansial antara pilihan yang dibuat serta efek yang dirasakan dari formulasi kebijakan dalam prosesnya. Subskrip pada huruf D (s, $k, c)$ hanya memperjelas bahwa keterlambatan dalam tahapan-tahapan formulasi yang terjadi mungkin berbeda. Selanjutnya state menjadi penentu dan menyediakan sarana uji publik formulasi kebijakan. Akibatnya terjadi penundaan pengesahan kebijakan sebelum fakta bahwa formulasi kebijakan tersebut dijalankan sesuai dengan prosedur yang berlaku. Penundaan ini kemudian mengarah kepada pilihan yang lain untuk tindakan baru, dihasilkan dari paradigma information, action, dan consequences.

Huruf " $D$ " besar pada tautan information to action memberikan gambaran bahwa informasi menghasilkan tindakan yang memiliki konsekuensi, menghasilkan 


\section{Planning}

\section{Analysis}

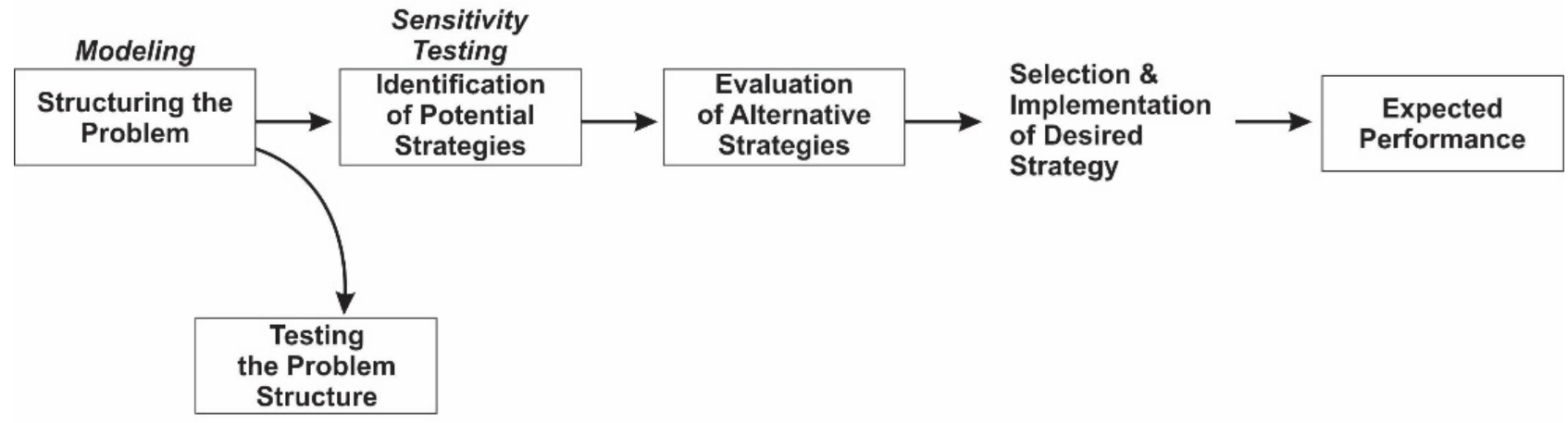

\section{Control}

Sumber: Lyneis (2009).

Gambar 3. Simulasi Model Sistem Dinamis Dalam Formulasi Kebijakan (1)

informasi dan tindakan lebih lanjut, dan sebagainya. Urutan dari ketiga komponen ini seiring berjalannya waktu merupakan perilaku dinamis. Formulasi akan berubah secara terus-menerus seiring berjalannya waktu dan pola perilaku akan tergantung pada seberapa baik informasi dan tindakan memengaruhi satu sama lain, dengan cara di mana konsekuensi akan muncul dalam sistem tertentu. Oleh sebab itu, pengetahuan memiliki peran yang sangat penting untuk menganalisis semua informasi yang masuk untuk memberikan kesimpulan apakah formulasi kebijakan dapat memiliki konsekuensi penundaan diakibatkan oleh informasi yang terus diterima oleh para pembuat kebijakan. Teknik-teknik sistem dinamis adalah alat yang dapat dicapai untuk membuat pola perilaku yang dapat diterima sebagaimana mestinya. Selain itu, rantai sebab dan akibat yang tertutup di mana informasi tentang hasil tindakan diumpankan kembali untuk menghasilkan tindakan lebih lanjut. Putaran umpan balik ini adalah elemen sentral dari teori teknik kontrol dan sistem dinamis. Umum terjadi terdapat pertanyaan yang menyiratkan bahwa harus ada seperangkat kriteria untuk mengontrol formulasi. Kriteria bukanlah masalah yang sederhana, karena beberapa aspek mungkin lebih penting dari pada yang lain dan mungkin perlu untuk saling melengkapi dengan cara menukar kriteria satu sama lain. Gagasan untuk menukar antara kriteria berarti bahwa kita harus mengerti apa yang seharusnya dicapai, dan hal itu mungkin tergantung pada keadaan.

\section{Simulasi Formulasi Kebijakan Dengan Dynamic System Model}

Bagian ini akan membahas simulasi formulasi kebijakan dengan menggunakan sistem dinamis. Di dalam kasus penelitian ini simulasi formulasi kebijakan mengambil contoh kebijakan pemerintah daerah tentang penguatan ekonomi kerakyatan. Oleh sebab itu, untuk menerangkan kegiatan formulasi kebijakan penelitian ini mengadopsi aspek analysis, planning, dan control yang dikembangkan oleh (Lyneis, 2009). Selanjutnya akan dimanifestasikan dalam serangkaian kegiatan Model Sistem Dinamis divisualisasikan pada Gambar 3.

Gambar 3 menerangkan serangkaian kegiatan untuk mengidentifikasi berbagai kemungkinan yang dapat diintroduksi dalam formulasi kebijakan. Model ini menyediakan sarana untuk menilai kemungkinan penyebab penyimpangan, dan dengan demikian memberikan peringatan dini tentang perlunya tindakan lanjutan. Sebagai ilustrasi, model di atas adalah kendaraan untuk dianalisis apakah pemahaman kita tentang sistem tercermin dalam persamaan model dinamis. Pada kenyataannya terus menghasilkan perilaku (analysis, planning, control) yang konsisten dengan masalah yang diamati, dan jika tidak, bagaimana pemahaman kita tentang struktur dapat dibuat lebih konsisten dengan kenyataan. Kegiatan yang dinamis akan menghasilkan berbagai kemungkinan analisis dari berbagai sumber, informasi, metode, referensi untuk menetapkan umpan balik dari semua analisis dalam sistem dinamis. Sebagai contoh, kegiatan dinamis formulasi kebijakan (kebijakan ekonomi kreatif pemerintah daerah) diilustrasikan pada Tabel 1.

Pertama-tama, kegiatan untuk mengidentifikasi struktur masalah mengambarkan sebuah situasi masalah, di mana masalah tidak terlepas dari 
Tabel 1. Kegiatan Dinamis Formulasi Kebijakan (Kebijakan Ekonomi Kreatif Pemerintah Daerah)

\begin{tabular}{|c|c|c|c|c|}
\hline Struktur Masalah & $\begin{array}{c}\text { Identifikasi Strategi } \\
\text { Potensial }\end{array}$ & $\begin{array}{l}\text { Evaluasi Alternatif } \\
\text { Masalah }\end{array}$ & $\begin{array}{c}\text { Seleksi, Implementasi } \\
\text { Strategi yang } \\
\text { Diinginkan }\end{array}$ & Kinerja yang Diharapkan \\
\hline $\begin{array}{l}\text { "Ekonomi } \\
\text { masyarakat (tingkat } \\
\text { pendapatan, } \\
\text { peluang usaha, } \\
\text { produksi dan } \\
\text { pemasaran, multi } \\
\text { player effect)" }\end{array}$ & $\begin{array}{ll}\text { - } & \text { Upaya pembangunan } \\
\text { infrastruktur } \\
\text { - Sosialisasi dan } \\
\text { pelatihan } \\
\text { - } \text { Difusi } \\
\text { - Teknologi informasi } \\
\text { - Kearifan lokal }\end{array}$ & $\begin{array}{l}\text { - } \quad \text { Difusi kebijakan } \\
\text { - Inovasi kebijakan } \\
\text { - } \\
\text { Derivate } \\
\text { kebijakan }\end{array}$ & $\begin{array}{l}\text { Berdasarkan budaya, } \\
\text { jaringan kebijakan } \\
\text { antara desain } \\
\text { kebijakan dan dampak } \\
\text { sosio-politik }\end{array}$ & $\begin{array}{l}\text { Meningkatnya } \\
\text { perekonomian dan } \\
\text { pendapatan masyarakat } \\
\text { dengan perluasan dan } \\
\text { perlindungan peluang } \\
\text { usaha }\end{array}$ \\
\hline
\end{tabular}

Sumber: Diolah dari berbagai sumber (2019).

manusia yang merasakan dan manusia juga yang akan menganalisis masalah itu sendiri (Dunn, 2016). Oleh sebab itu, struktur yang benarbenar mencerminkan masalah yang mesti segera diselesaikan yang berhubungan dengan kepentingan masyarakat. Struktur masalah dirancang untuk meningkatkan konten informasi dan abstraksi, informasi dari masalah sering membutuhkan informasi tentang kondisi antiseden masalah dan informasi tentang nilai-nilai yang mendorong solusi dari masalah itu sendiri. Informasi tentang masalah kebijakan biasanya termasuk alternatif solusi, dan jika tersedia probabilitas setiap solusi alternatif kemungkinan akan menyebabkan penyelesaian. Informasi masalah yang diintroduksi dalam kebijakan memainkan peran penting dalam analisis kebijakan, karena cara tersebut merupakan masalah terstruktur dan akan mengatur identifikasi solusi. Langkah kedua mengidentifikasi strategi yang potensial, cara ini akan membawa pembuat kebijakan dengan hatihati menentukan cara yang paling potensial untuk diintroduksi sebagai solusi dalam kebijakan. Dengan demikian Hoppe (2018) menunjukkan, solusi yang ditawarkan dalam kebijakan berasal dari prinsip struktur masalah yang teridentifikasi melalui problem sensitivity, frame reflectiveness, alternating forward and backward mapping, dan moving back and forth between puzzling and powering.

Langkah ketiga mengevaluasi alternatif strategi, kegiatan ini memberikan informasi bahwa ketika kebijakan yang dibahas belum tentu alternatif solusi yang ditawarkan akan diterima oleh mayoritas anggota pembuat kebijakan. Diperlukan alternatif solusi yang lain untuk menjamin siklus pembahasan

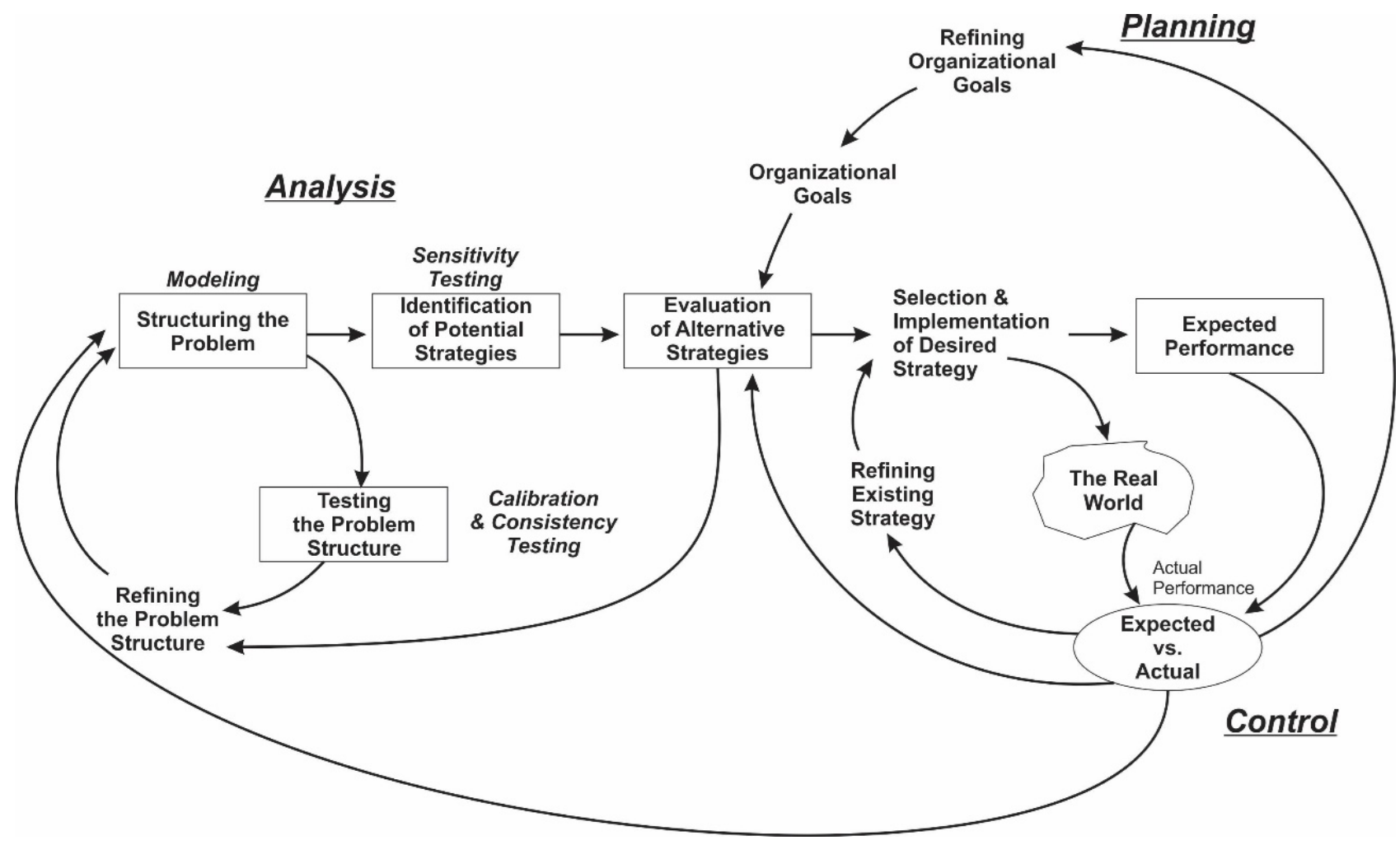

Sumber: Lyneis (2009).

Gambar 4. Simulasi Model Sistem Dinamis dalam Formulasi Kebijakan (2) 
tetap berjalan. Langkah keempat memastikan pilihan solusi masalah yang diinginkan untuk direduksi dalam kebijakan. Proses mengevaluasi strategi alternatif sering memberi titik terang baru pada masalah yang dihadapi atau mengungkapkan perlunya analisis lebih lanjut. Hoppe (2010) memberikan rambu kehati-hatian dalam implementasi solusi yang diinginkan dalam kebijakan dan turut memerhatikan hal mendasar dari budaya, jaringan kebijakan antara desain kebijakan dan dampak sosio-politik. Langkah kelima merupakan harapan dari tujuan yang ingin dicapai melalui kebijakan, kegiatan ini akan melalui serangkaian kegiatan yang melibatkan berbagai cara seperti menelaah kembali substansi kebijakan antara program dan evaluasi (Trochim, 2009; Sayyadi \& Awasthi, 2016).

Siklus "pemodelan sistem dinamis" adalah kegiatan berulang dan membandingkan perilaku yang disimulasikan dengan kinerja aktual, metode ilmiah yang diterapkan untuk strategi. Simulasi model menunjukkan bagaimana struktur kebijakan dan peristiwa eksternal bersama-sama menyebabkan kinerja organisasi (pelaksana kebijakan) di masa lalu, dan bagaimana kinerja masa depan akan berkembang jika struktur, kebijakan, dan peristiwa eksternal berbeda. Kegiatan Model Sistem Dinamis lanjutan formulasi kebijakan dalam penelitian ini divisualisasikan pada Gambar 4.

Ada sejumlah informasi pada Gambar 4, di mana pendekatan Model Sistem Dinamis dapat dan telah terhubung dari sejumlah faktor yang dapat terjadi. Sebagai contoh formulasi kebijakan tentang ekonomi kreatif pemerintah daerah, konsep-konsep seperti difusi kebijakan, inovasi kebijakan, derivate kebijakan, skala ekonomi, atau lingkup ekonomi yang menjadi landasan dasar kebijakan akan menentukan koneksi yang mungkin terjadi antara sumber daya dan biaya, model dinamis pada umumnya mewakili hal seperti itu. Formulasi kebijakan yang sedang berjalan melibatkan pemantauan kinerja yang sistematis dan berkesinambungan serta umpan balik yang efektif atas keberhasilan, masalah, ancaman, peluang, pengalaman, dan pelajaran yang diperoleh dari komponen lain dari proses formulasi kebijakan itu sendiri.

Lebih lanjut, "analisis" biasanya dipicu oleh penyimpangan yang signifikan antara kinerja aktual dan yang diharapkan. Hal ini melibatkan penataan berulang, pengujian, dan perbaikan dan pemahaman organisasi tentang masalah-masalah operasional atau strategi dan opsi-opsi yang terbuka untuk menghadapi kesenjangan. Testing the problem structure, calibration \& consistency testing, refining the problem structure adalah kegiatan untuk memastikan setiap masalah yang menjadi dasar kebijakan dapat mewakili berbagai kelompok kepentingan. Namun Lyneis (2009); Wheat (2010); Bérard, et al. (2016); Estrada \& Park (2018) mengingatkan bahwa struktur masalah yang diintroduksi dalam berbagai kebijakan setidaknya mencerminkan masalah yang aktual dan situasi yang kompleks.

Refining organizational goal, organizational goal, mengindikasikan kegiatan untuk menyeleksi berbagai tujuan organisasi yang direncanakan akibat dari berlakunya kebijakan. Selain itu, tujuan merefleksikan kemungkinan berbagai cara analisis tertentu untuk dapat menjelaskan tujuan kebijakan itu sendiri. Di beberapa kasus tujuan dari kebijakan setidaknya akan menjunjung tinggi transparansi dan keterbukaan publik bagi organisasi (Dawes, 2010). Obyek sasaran kebijakan juga melibatkan aparatur pelaksana organisasi untuk dapat menilai sejauh mana kebijakan tersebut dapat memengaruhi internal organisasi (Arnold, 2014), dan lebih jauh tujuan tersebut teridentifikasi dari berbagai kegiatan "agenda setting" kebijakan yang selalu berubah untuk mendapatkan kemungkinan-kemungkinan yang lebih baik dari apa yang telah ditetapkan (Liu, et al., 2010; Mortensen, 2010). Oleh sebab itu, "perencanaan", juga merupakan proses berulang, hal ini melibatkan evaluasi, seleksi, dan implementasi kebijakan/strategi. Strategi alternatif tidak hanya tergantung pada pencapaian yang diproyeksikan dari tujuan organisasi, tetapi juga pada realitas kinerja saat ini. Kebijakan operasional yang ada atau strategi yang ada (visi, misi, strategi) dan sasaran dapat diperbaiki, seperti yang dipersyaratkan berdasarkan keberhasilan dan masalah yang dihadapi sebagai tanggapan terhadap perubahan.

Refining existing strategy, real world (actual performance) melibatkan serangkaian kegiatan untuk memilih strategi yang paling tepat untuk di introduksi dalam kebijakan dari sekian banyak alternatif strategi. Hal ini mengandung makna bahwa pilihan strategi setidaknya mengandung informasi kebaruan. Sebagai contoh, studi yang dilakukan Wheat (2010) menemukan bahwa implementasi kebijakan publik dapat meningkatkan kemampuan berpikir operasional yang diperlukan untuk merancang model struktur kebijakan sektor publik. Kegiatan seperti ini mencerminkan pembelajaran dari kebijakan yang diimplementasikan, bagaimana kebijakan tersebut dapat dilihat dari aspek yang mengelilingi kebijakan itu sendiri. Oleh sebab itu, model berbasis sistem dinamis terbatas pada perubahan pengujian, bukannya merancang dan mengujistrukturkebijakan baru namun untukmencari perbaikan perilaku kebijakan dan memerlukan perbaikan dalam struktur kebijakan itu sendiri 
dalam merancang formulasi kebijakan berikutnya (Richardson, 1991; Wheat, 2010; Navarra \& Bianchi, 2013). Lebih lanjut, ekspektasi atau harapan dan kenyataan dalam formulasi dapat mewakili keadaan yang nyata dan terus berubah setiap saat (Trailer \& Garsson, 2005; Loftis \& Mortensen, 2017). Dengan demikian "kontrol" adalah tempat organisasi terus belajar, kegiatan ini memberikan elemen penting proses kontrol perkiraan kinerja yang diharapkan terhadap kinerja aktual yang dapat dipantau secara teratur. Penyimpangan memberikan sinyal untuk analisis tambahan, apakah kebijakan/strategi telah diterapkan secara efektif.

Model Sistem Dinamis merupakan metodologi yang membantu kita mendesain lebih baik dan menanggapi sistem yang kompleks (Findiastuti, et al., 2018; Kunc, et al., 2018). Pada kenyataannya, semua struktur sosial dan sistem yang kompleks dimulai dari mengamati dan menanggapi sifat sistem yang kompleks, struktur yang saling berhubungan yang diisi dengan loop umpan balik di mana perilaku dan tindakan di salah satu bagian dari dampak sistem atau dibatasi oleh bagian lain dari sistem. Mereka dicirikan dari perilaku berlawanan (non linier), di mana tidak hanya berpengaruh dengan penyebabnya, tetapi sering jauh terpisah dalam sistem pemodelan. Dengan kata lain, efek atau perubahan satu bagian dari sistem jauh berbeda dari pada yang dimaksudkan karena perubahan menyebabkan efek dinamis dalam sistem secara keseluruhan. Kompleksitas ini membuat semua sistem inheren sulit untuk memahami secara intuitif dan terjadi resisten kebijakan karena keputusan para pembuat kebijakan sering memperoleh respon yang tidak diinginkan (Hoppe, 2018; Vrat, 2018).

Lebih lanjut, dari penelusuran beberapa studi yang pernah dilakukan teridentifikasi langkahlangkah untuk mengerjakan kajian Model Sistem Dinamis yang berlaku secara umum, yaitu:

a. Konseptualisasi (dynamic review)

Identifikasi struktur masalah (fenomena), kegiatan ini dimulai dari memetakan berbagai masalah isu-isu kebijakan publik mereplikasi perilaku dinamis yang bermasalah. Sebuah prinsip dasar Model Sistem Dinamis adalah struktur umpan balik sistem menentukan perilaku dinamis. Beberapa praktisi dan akademisi menuliskan identifikasi masalah antara kebijakan yang telah dilakukan dengan identifikasi potensi keberhasilan masa depan kebijakan yang rancang. Untuk memudahkan identifikasi masalah biasanya dilakukan dengan jumlah (angka) yang teridentifikasi, kemudian angka tersebut ditabelkan agar memudahkan menjelaskan dalam bentuk deskriptif (Albin,
1997; Lyneis, 2009; Wheat, 2010). Selain itu, model yang sering digunakan untuk menjelaskan jumlah (angka) tersebut menggunakan Pareto Chart (lihat lebih lanjut Ghaffarzadegan, et al., 2011), dan Base Case-Model (lihat lebih lanjut Wheat, 2010).

b. Formulasi (feedback)

Kegiatan ini untuk mengkonversi umpan balik, artinya bahwa ikatan yang erat di antara para aktor, tindakan memberi umpan balik pada keputusan dan kemungkinan akan dapat mengubah apa yang telah dilakukan untuk memicu orang lain bertindak, sehingga memunculkan situasi baru yang kemudian memengaruhi keputusan selanjutnya (Albin, 1997; Sterman, 2000; Chen, et al., 2011). Kegiatan ini merupakan bentuk lingkaran bolak balik untuk mengetahui sejauh mana masalah dan mempersempit masalah yang teridentifikasi. Dengan mengamati, mengevaluasi, mengambil tindakan baru, menghasilkan hasil baru, pengamatan, tindakan lebih lanjut, dan sebagainya (Barlas, 2002). Untuk memiliki model yang bermakna, harus ada beberapa masalah mendasar dalam sistem yang menciptakan suatu kebutuhan analisis umpan balik. Model yang sering digunakan untuk tahap ini adalah Causal Loop Structure, Behaviour of Base-Case (lihat lebih lanjut Wheat, 2010), dan Model Boundary (lihat lebih lanjut Albin, 1997).

c. Pengujian (validity, validation aspect, policy analysis)

Tahap ini mensimulasikan model dan menguji hipotesis yang dinamis, uji asumsi model, dan uji model perilaku dan kepekaan terhadap gangguan. Validasi adalah proses yang berkepanjangan dan rumit, yang melibatkan perangkat formal/kuantitatif dan informal/ kualitatif. Aspek formal validasi dan taksonomi dari berbagai aspek dan langkah validasi (Barlas, 2002). Model dapat diklasifikasikan dalam berbagai cara, sesuai dengan kriteria yang berbeda, seperti fisik vs simbolik; dinamis vs statis, dan lain-lain. Terkait dengan gagasan validitas, perbedaan krusial harus dibuat antara model yang "deskriptif sebab akibat" (seperti teori) dan model yang murni "korelasional" (murni berbasis data). Dalam model murni korelasional tidak ada klaim kausalitas dalam struktur, yang penting adalah model dinilai valid jika output-nya cocok dengan beberapa kisaran akurasi tertentu. Validasi ini seringkali dapat dianggap sebagai masalah pengujian statistik klasik, dibuat terutama untuk tujuan perkiraan. Di sisi lain, model kausal-deskriptif adalah pernyataan tentang bagaimana sistem secara 
nyata beroperasi dalam beberapa aspek. Dalam hal ini, menghasilkan output keluaran lebih akurat dan tidak cukup hanya dengan validitas saja. Tahap ini lebih sering menggunakan References Modes (lihat lebih lanjut Albin, 1997).

d. Penggunaan alat (software)

Pembuatan Model Sistem Dinamis dapat menggunakan beberapa software di antaranya dynamo, vensim, stella, l-think, dan powersim. Seperti misalnya powersim adalah software simulasi untuk sistem dinamis dengan menggunakan metodologi pemodelan berbasis komputer. Simbol yang dipakai untuk mewakili parameter terukur 'Level', 'Reservoir', 'Auxiliary', dan 'Constant' serta penghubung 'Flow Rate' dan 'Link' dapat dikaitkan satu sama lain untuk menjalin sebuah sistem yang kompleks.

Di sisi yang lain, Model Sistem Dinamis terdapat perbedaan antara sistem yang sederhana dan kompleks, dan sering berlawanan satu sama yang lain antara setiap bagian dalam sistem yang dinamis (Sterman, 2000; Palm III, 2014). Sebagai contoh, dalam sistem yang kompleks penyebab utama sebenarnya berasal dari "perilaku", mungkin berasal dari bagian lain dari sistem dan sering dari tempat yang tidak diprediksi sebelumnya atau dari tempat di luar sistem. Akibatnya dalam sistem yang kompleks, mencapai tujuan jangka pendek berarti terdapat konsekuensi jangka panjang yang tidak diinginkan, dan dalam sistem yang kompleks keputusan yang jelas sering ternyata menjadi salah satu yang tidak efektif (Workman, et al., 2009). Sebuah Model Sistem Dinamis adalah representasi dari struktur sistem, seperti semua model tidak pernah sepenuhnya menggambarkan hal yang akurat dari perilaku yang diamati (termasuk struktur masalah). Namun, alat-alat sistem dinamis memberikan sarana untuk menggali pengetahuan yang mendasari model dengan representasi yang lebih akurat dari kompleksitas sistem. Untuk membangun sebuah model yang berguna membutuhkan ruang lingkup sistem, dan pemodelan sistem dinamis yang berbeda akan tergantung pada mendefinisikan ruang lingkup dari masalah (Trailer \& Garsson, 2005; Wheat, 2010; Groff, 2013). Sebagai contoh studi yang dilakukan oleh Findiastuti, et al. (2018) tentang penilaian kebijakan ketersediaan pangan berkelanjutan Indonesia, simulasi model dirancang dan dijalankan untuk menjawab pertanyaan "bagaimana-jika" untuk opsi skenario kebijakan pemerintah Indonesia dalam mencapai ketersediaan pangan berkelanjutan. Oleh sebab itu, pertama mereka mengidentifikasi masalah sebagai sistem yang holistik melalui aspek ekonomi, sosial, dan lingkungan (dynamic review).
Masalah tersebut diidentifikasi saling terkait, hubungan antara elemen-elemen masalah tersebut disusun dan digambarkan dalam Causal Loop Structure, kemudian disimulasikan melalui Stock-flow Diagram. Bertujuan untuk mencapai persyaratan minimum skor ketersediaan makanan dan rasio ketersediaan pangan yang tinggi (feedback). Kemudian Findiastuti, et al. (2018) menegaskan bahwa menganalisis hasil ini tanpa evaluasi lebih lanjut dalam pandangan sistemik dapat menyebabkan kesalahan persepsi (validity, validation aspect, policy analysis). Hal ini menunjukkan serangkaian tes untuk memastikan bahwa model yang dibangun untuk mewakili dunia nyata dengan cara membandingkan hasil simulasi dengan data historis. Untuk mempermudah analisis data-data yang dihimpun digunakan perangkat lunak untuk menguji hipotesis. Di sisi yang lain penggunaan Model Sistem Dinamis akan memudahkan perencanaan atau menilai sesuatu yang dapat diukur melalui informasi yang kompleks untuk menghasilkan kesimpulan dan mewakili berbagai fenomena yang aktual dengan segala kemungkinan yang memengaruhi. Sehingga penggunaan Model Sistem Dinamis dapat merefleksikan kesesuian antara kenyataan dan data (Barlas, 2002; Lyneis, 2009; Kunc, et al., 2018; Findiastuti, et al., 2018).

\section{KESIMPULAN}

Model Sistem Dinamis adalah sebuah sistem yang mencoba untuk menjelaskan perilaku dari berbagai tindakan dalam sebagian sistem. Selain dikatakan sebagai sistem tertutup, sistem dinamis juga merupakan sistem umpan balik. Terdapat dua macam umpan balik, yaitu umpan balik positif dan umpan balik negatif. Umpan balik negatif adalah suatu proses untuk mencapai tujuan (goal seeking). Feedback ini cenderung menjadi penyeimbang terhadap setiap gangguan dan selalu membawa sistem dalam keadaan yang stabil. Sedangkan umpan balik positif terjadi jika perubahan dalam komponen sistem akan menyebabkan terjadinya perubahan di dalam komponen lain yang akan memperkuat proses awalnya. Umpan balik positif merupakan proses yang sifatnya tumbuh dan berkembang untuk menilai beberapa faktor tambahan yang diindikasikan dapat terjadi.

Simulasi model yang telah diintroduksi dalam penelitian ini menggambarkan bahwa formulasi kebijakan "perlu" mengadopsi sistem dinamis untuk menghindari kebijakan yang tidak berkualitas. Semakin kompleks hal-hal yang diperkirakan dapat memengaruhi untuk dianalisis, maka kemungkinan kebijakan yang dihasilkan dapat merepresentasikan tujuan berdasarkan masalah yang teridentifikasi. Sementara itu dalam model dinamis perilaku 
kebijakan dalam struktur yang dianalisis setiap saat dapat berubah dan memungkinkan skema umpan balik memberikan arus informasi untuk merancang formulasi kebijakan yang lebih kompleks. Dari beberapa studi yang terungkap para peneliti dan akademisi memberikan penjelasan bahwa Model Sistem Dinamis tidak secara absolut merujuk kepada satu gambar model dinamis, namun Model Sistem Dinamis dibentuk dari kekuatan untuk melihat fenomena masalah, tindakan memberi umpan balik pada keputusan dan kemungkinan yang dapat mengubah apa yang telah dilakukan, dan pengujian yang direpresentasikan dengan sebuah gambar agar dapat dipahami secara deskriptif untuk menghasilkan kesimpulan secara hati-hati.

Saran yang dapat diajukan dari pembahasan dalam artikel penelitian ini adalah bagi para pembuat kebijakan, Model Sistem Dinamis berguna untuk melakukan analisis berbagai informasi sebagai bahan formulasi kebijakan. Karena kebijakan mesti sebagai petunjuk untuk mengatur, dan menjalankan berbagai program. Lebih lanjut dengan menggunakan Model Sistem Dinamis diharapkan dapat menghasilkan kebijakan yang tidak di-yudicial review. Artinya bahwa ketika kebijakan diuji kembali maka diindikasikan bahwa kebijakan tersebut bermasalah. Akhirnya bagi peneliti masa depan, artikel penelitian ini dapat digunakan sebagai referensi tambahan untuk mengkaji penerapan Model Sistem Dinamis pada konteks yang berbeda dalam studi kebijakan publik, sehingga dengan banyaknya informasi yang tersedia akan memudahkan memahami Model Sistem Dinamis dalam praktik.

\section{DAFTAR PUSTAKA}

\section{Buku}

Albin, S. (1997). Building a System Dynamics Model Part 1: Conceptualization. Massachusetts: Massachusetts Institute of Technology.

Barlas, Y. (2002). System Dynamics: Systematic feedback medeling for policy analysis. In $\mathrm{Y}$. Barlas (Ed.). System Dynamics (h. 1-68). Abu Dhabi: Encyclopedia of Life Support Systems (EOLSS).

Barnett, E. \& Thomas, J. (2009). Methods for the synthesis of qualitative research: A critical review. National Centre for Research Methods Working Papers Series, (EPPI) Centre, Social Science Research Unit, Institute of Education, London.
Bender, K., Keller, S., \& Willing, H. (2014). The role of international policy transfer and diffusion for policy change in social protection-A review of the state of the art. International Policy Learning and Policy Change: Scientific Inputs for the Dialogue on Social Protection with Global Partners (h. 1-18). Bonn: Deutsche Gesellschaft für Internationale Zusammenarbeit (GIZ) $\mathrm{GmbH}$ and Bonn-Rhein-Sieg University of Applied Sciences / International Centre for Sustainable Development (IZNE).

Coyle, R. (1996). System Dynamics Modelling: A practical approach. New York: SpringerScience+Business Media.

Dey, I. (1993). Qualitative data analysis: A userfriendly guide for social scientists. London: Routledge.

Duggan, J. (2016). System Dynamics Modeling with R. Switzerland: Springer International Publishing.

Dunn, W.N. (2016). Public policy analysis (5th ed.). Oxon: Routledge.

Dye, T.R. (2013). Understanding public policy (14th ed.). Upper Saddle River, NJ: Pearson Education.

Hill, M. (2005). The Public policy process (4th ed.). Essex: Pearson Education.

Hoppe, R. (2010). The Governance of problems: Puzzling, powering, participation. Bristol: The Policy Press.

Howlett, M. (2011). Designing public policies: Principles and instruments. Oxon: Routledge.

Kay, A. (2006). The dynamics of public policy: Theory and evidence. Cheltenham: Edward Elgar.

Luenberger, D.G. (1979). Introduction to Dynamic System: Theory, models and applications. New York: John Wiley \& Sons.

Lyneis, J.M. (2009). Business policy and strategy, System Dynamics Applications to. In R.A. Meyers (Ed.). Encyclopedia of complexity and systems science (h. 69-92). New York: Springer.

Palm III, W.J. (2014). System Dynamics (3rd ed.). New York, NY: McGraw-Hill.

Paterson, B.L., Thorne, S.E., Canom, C., \& Jillings, C. (2001). Meta-study of qualitative health research: A practical guide to meta-analysis and meta-synthesis. Thousand Oaks, CA: SAGE Publication. 
Richardson, G.P. (1991). System Dynamics: Simulation for policy analysis from a feedback perspective. In P.A. Fishwick (Ed.). Qualitative simulation modeling and analysis (h. 144-156). New York: Springer-Verlag.

Richardson, G.P. \& Pugh, A.L. (1981). Introduction to System Dynamics Modeling with DYNAMO. Massachusetts: The Massachusetts Institute of Technology.

Rowell, D. \& Wormley, D. N. (1997). System Dynamics: An introduction. Upper Saddle River, NJ: Prentice-Hall.

Sterman, J.D. (2000). Business Dynamics Systems thinking and modeling for a complex world. Boston: McGraw-Hill Higher Education.

Stewart, J. (2009). Public policy values. Hampshire: Palgrave Macmillan.

\section{Jurnal}

Aghion, P., Algan, Y., Cahuc, P., \& Shleifer, A. (2010). Regulation and distrust. The Quarterly Journal of Economics, 125(3), 1015-1049. doi:10.3386/ w14648.

Arnold, G. (2014). Policy learning and science policy innovation adoption by street-level bureaucrats. Journal of Public Policy, 34(3), 389-414. doi:10.1017/S0143814X14000154.

Bérard, C., Cloutier, L.M., \& Cassivi, L. (2016). The effects of using System Dynamics-based decision support models: Testing policy-makers boundaries in a complex Situation. Journal of Decision Systems, 26(1), 45-63. doi:10.1080/12 460125.2016.1204212.

Bovens, M. \& Hart, P. (2016). Revisiting the study of policy failures. Journal of European Public Policy, 23(5), 653-666. doi:10.1080/13501763.2015.11 27273.

Chen, Y.T., Tu, Y.M., \& Jeng, B. (2011). A machine learning approach to policy optimization in System Dynamics Models. Systems Research and Behavioral Science, 28(1), 369-390. doi:10.1002/ sres.1089.

Dawes, S.S. (2010). Stewardship and usefulness: Policy principles for information-based transparency. Government Information Quarterly, 27(4), 377383. doi:10.1016/j.giq.2010.07.001.

Estrada, M.A. \& Park, D. (2018). The past, present and future of policy modeling. Journal of Policy Modeling, 40(1), 1-15. doi:10.1016/j. jpolmod.2018.01.003.
Findiastuti, W., Singgih, M.L., \& Anityasari, M. (2018). Indonesian sustainable food availability policy assessment using System Dynamics: A solution for complexities. Cogent Food \& Agriculture, 4(1455795), 1-21. doi:10.1080/23311932.2018. 1455795 .

Ghaffarzadegan, N., Lyneis, J., \& Richardson, G.P. (2011). How small System Dynamics Models can help the public policy process. System Dynamics Review, 27(1), 22-44. doi:10.1002/sdr.442.

Gilardi, F. (2016). Four ways we can improve policy diffusion research. State Politics \& Policy Quarterly, 16(1), 8-21. doi:10.1177/1532440015608761

Groff, J.S. (2013). Dynamic Systems Modeling in educational system design \& policy. New Approaches in Educational Research, 2(2), 7281. doi:10.7821/naer.2.2.72-81.

Henriksen, L.F. (2013). Economic Models as devices of policy change: Policy paradigms, paradigm shift, and performativity. Regulation \& Governance, 7(4), 481-495. doi:10.1111/rego.12031.

Homer, J.B. \& Hirsch, G.B. (2006). System Dynamics Modeling for public health: Background and opportunities. American Journal of Public Health, 96(3), 452-458. doi:10.2105/AJPH.2005.062059.

Hoppe, R. (2018). Rules of thumb for problem structuring policy design. Policy Design and Practice, 1(1), 12-29. doi:10.1080/25741292.20 18.1427419.

Howlett, M. (2012). The Lessons of failure: Learning and blame avoidance in public policy-making. International Political Science Review, 33(5), 539-555. doi:10.1177/0192512112453603.

Kunc, M., Morecroft, J.D., \& Brailsford, S. (2018). Special issue on advances in system dynamics modelling from the perspective of other simulation methods. Journal of Simulation, 12(2), 87-89. doi:10.1080/17477778.2018.1469 385.

Liu, X., Lindquist, E., Vedlitz, A., \& Vincent, K. (2010). Understanding local policymaking: Policy elites' perceptions of local agenda setting and alternative policy selection. The Policy Studies Journal, 38(1), 69-91. doi:10.1111/j.15410072.2009.00345.x.

Loftis, M.W. \& Mortensen, P.B. (2017). A Dynamic Linear Modelling approach to public policy change. Journal of Public Policy, 1-27. doi:10.1017/S0143814X17000186. 
Maggetti, M. \& Gilardi, F. (2015). Problems (and solutions) in the measurement of policy diffusion mechanisms. Journal of Public Policy, 00(0), 1-21. doi:10.1017/S0143814X1400035X.

Mortensen, P.B. (2010). Political attention and public policy: A study of how agenda setting matters. Scandinavian Political Studies, 33(4), 256-380. doi:10.1111/j.1467-9477.2010.00254.x.

Navarra, D. \& Bianchi, C. (2013). Territorial governance, e-government and sustainable development policy: A System Dynamics Approach. 12th International Conference on Electronic Government (EGOV), pp. 14-25.

Rashedi, R. \& Hegazy, T. (2015). Strategic policy analysis for infrastructure rehabilitation using System Dynamics. Structure and Infrastructure Engineering, 12(6), 667-681. doi:10.1080/15732 479.2015.1038723.

Sayyadi, R. \& Awasthi, A. (2016). A System Dynamics based simulation model to evaluate regulatory policies for sustainable transportation planning. International Journal of Modelling and Simulation, 37(1), 25-35. doi:10.1080/02286203 .2016.1219806.

Trailer, J.W. \& Garsson, K. (2005). A System Dynamics Approach to assessing public policy impact on the sustainable growth rate of new ventures. New England Journal of Entrepreneurship, 8(1), 1-14.

Trochim, W.M. (2009). Evaluation policy and evaluation practice. New Directions for Evaluation, 123(1), 13-32. doi:10.1002/ev.303.
Uriona, M. \& Grobbelaar, S.S. (2018). Innovation system policy analysis through System Dynamics Modelling: A systematic review. Science and Public Policy, 46(1), 28-44. doi:10.1093/scipol/ scy034

Vrat, L.U. (2018). Policy boomerang in technical education: A System Dynamics perspective. Journal of Advances in Management Research, 14(2), 1-33. doi:10.1108/JAMR-08-2016-0065.

Wheat, I.D. (2010). What can System Dynamics learn from the public policy implementation literature? Systems Research and Behavioral Science, 27(1), 425-442. doi:10.1002/sres.1039.

Workman, S., Jones, B.D., \& Jochim, A.E. (2009). Information processing and policy dynamics. The Policy Studies Journal, 37(1), 75-92.

\section{Sumber Digital}

Kemendagri. (2016). Unggah 3.143 Perda, Mendagri berterimakasih ke semua pihak. Diperoleh tanggal 21 Juni 2018, dari http://www. kemendagri.go.id/news/2016/06 /21/unggah3143-perda-mendagri-berterimakasih-kesemua-pihak.

\section{Peraturan}

Peraturan Presiden Republik Indonesia No. 104 tahun 2007 tentang Penyediaan, Pendistribusian, dan Penetapan Harga Liquefied Petroleum Gas (LPG) Tabung 3 Kilogram 